\title{
PRINSIP-PRINSIP KONTRAK KONSTRUKSI INDONESIA
}

\author{
Sugiarto Raharjo Japar \\ Universitas Airlangga \\ sugiartoraharjojapar@hotmail.com
}

\begin{abstract}
The implementation of construction services must meet the principles of honesty and fairness, benefits, compatibility, balance, independency, openness, partnership and safety foremost in the interest of the community, nation and the state (article 2 act no 18 years 1999 on construction services ).Then both users and providers services need to understand some of the stuff that fundamental i.e. the runway philosophical contractual relationship between providers of the construction services to the construction services and inspector construction services, the principle and legal norm the formation of legal construction contract, the principle and legal norm the implementation of legal construction contract. The legal research method in this journal uses a normative juridical research method with a statute approach that examines relevant laws and regulations and the conceptual approach that examines the theories and doctrines of experts in the field construction.
\end{abstract}

Keywords: construction services company, construction contract in Indonesia.

\begin{abstract}
ABSTRAK
Penyelenggaraan jasa konstruksi harus memenuhi asas kejujuran dan keadilan, manfaat, keserasian, keseimbangan, kemandirian, keterbukaan, kemitraan dan keselamatan demi kepentingan masyarakat, bangsa dan negara (Pasal 2 UndangUndang Nomor 18 Tahun 1999 Tentang Jasa Konstruksi). Maka baik pengguna jasa maupun penyedia jasa harus memahami beberapa hal yang mendasar yaitu: Landasan Filosofis Hubungan Kontraktual Antara Pemberi Jasa Konstruksi dengan Penyedia Jasa Konstruksi dan Pengawas Jasa Konstruksi, Prinsip dan Norma Hukum Fase Pembentukan Kontrak Konstruksi, Prinsip dan Norma Hukum Fase Pelaksanaan Kontrak Konstruksi. Metode penelitan hukum pada jurnal ini menggunakan metode penelitian yuridis normatif dengan pendekatan perundang-undangan (statute approach) yang mengkaji undang-undang dan peraturan yang relevan serta pendekatan konseptual (conseptual approach) yang mengkaji teori-teori dan doktrindoktrin dari para ahli di bidang konstruksi.
\end{abstract}

Kata kunci: penyelenggaraan jasa konstruksi, kontrak konstruksi di Indonesia

\section{PENDAHULUAN}

Pelaksanaan kegiatan konstruksi yang meliputi kegiatan perencanaan, pelaksanaan, dan pengawasan terhadap bangunan sangat dibutuhkan adanya suatu acuan/dasar hukum yang berfungsi sebagai pedoman di dalam penyelenggaraannya. Landasan hukum yang dimaksud disini adalah berupa perikatan tertulis antara pemilik proyek/pemberi tugas yang disebut dengan pengguna jasa dan konsultan perencana, pelaksana dan pengawas yang dalam Undang-Undang Nomor 18 Tahun 1999 tentang Jasa Konstruksi dikenal sebagai penyedia jasa (Pasal 1 angka 1 UU Jasa Konstruksi). 
Perikatan tertulis inilah yang dikenal dengan istilah "Kontrak Konstruksi" atau "Perjanjian Konstruksi" yang dinegara barat dikenal dengan istilah Construction Contract atau Construction Agreement. ${ }^{1}$

Pengikatan dalam bentuk kontrak konstruksi ini menjadi sangat penting untuk dilakukan mengingat konstruksi dewasa ini merupakan bidang usaha jasa yang banyak diminati oleh anggota masyarakat di berbagai tingkatan, sebagaimana dapat dilihat dari semakin besarnya jumlah perusahaan/badan usaha yang bergerak di bidang usaha penyedia jasa konstruksi. Peningkatan jumlah perusahaan atau badan usaha ini belum diikuti dengan pemahaman oleh perusahaan atau badan usaha terkait dengan landasan filosofis hubungan kontraktual antara pemberi jasa konstruksi dengan penyedia jasa konstruksi dan pengawas jasa konstruksi, prinsip dan norma hukum tahap pembentukan kontrak konstruksi, prinsip dan norma hukum tahap pelaksanaan kontrak konstruksi. Termasuk juga kepatuhan/ketaatan para pihak di dalam pemenuhan kewajiban serta pemenuhan terhadap ketentuan-ketentuan yang telah disepakati kedua belah pihak di dalam kontrak konstruksi.

\section{METODOLOGI}

Metode penelitan hukum pada jurnal ini menggunakan metode penelitian yuridis normatif dengan pendekatan perundang-undangan (statute approach) yang mengkaji undang-undang dan peraturan yang relevan serta pendekatan konseptual (conseptual approach) yang mengkaji teori-teori dan doktrin-doktrin dari para ahli di bidang konstruksi.

\section{PEMBAHASAN}

\section{Pengaruh Paradigma Kebebasan Berkontrak}

Asas kebebasan berkontrak dalam sistem hukum Civil Law dan Common Law lahir dan berkembang seiring dengan pertumbuhan aliran filsafat yang menekankan semangat individualisme dan pasar bebas ${ }^{2}$. Pada abad sembilan belas, asas kebebasan berkontrak sangat diagungkan baik oleh para filosuf, para ekonom dan sarjana hukum mapun pengadilan. ${ }^{3}$ Kebebasan berkontrak sangat mendominasi teori hukum kontrak. ${ }^{4}$ Inti dari permasalahan hukum kontrak lebih ditekankan kepada realisasi kebebasan berkontrak. Pengadilan dalam hal ini juga lebih mengutamakan kebebasan berkontrak dibanding dengan nilai-nilai keadilan dalam setiap putusannya. Pengaturan melalui

\footnotetext{
${ }^{1}$ Nazarkhan Yasin, Mengenal Kontrak Konstruksi Di Indonesia, Gramedia Pustaka Utama, Jakarta, 2003, h.1.

${ }^{2}$ Friedrich Kessler, "Contract Adhesion-Some Thought About Freedom of Contract", Columbia Law Review, vol. 43, 1943, h. 630.

3 A.G Guest, ed., Chitty on Contract, Vol. I General Principles, Sweet \& Maxwell, London, 1983, h. 3. ${ }^{4}$ Alan J. Messe, "Liberty and Antitrust in the Formative Era", Boston University Law Review, vol. 79, 1999, h. 2.
} 
legislasi pun memiliki kecenderungan yang sama. Keberadaan asas kebebesan berkontrak tidak dapat dilepaskan dari pengaruh berbagai aliran filsafat politik dan ekonomi liberal yang berkembang pada abad kesembilanbelas. ${ }^{4}$ Dalam bidang ekonomi telah berkembang aliran laissez faire yang telah dipelopori oleh Adam Smith yang menekankan prinsip non-intervensi oleh pemerintah terhadap kegiatan ekonomi dan bekerjanya pasar ${ }^{5}$. Filsafat utilitarian Jeremy Bentham yang menekankan adanya ideologi free choice ${ }^{6}$ telah berpengaruh terhadap pertumbuhan asas kebebasan berkontrak tersebut. Baik pemikiran Adam Smith maupun Bentham didasarkan pada filsafat etika Immanuel Kant. ${ }^{7}$ Semua aliran filsafat yang menekankan pada aspek kebebasan individu yang telah dikembangan oleh para filosuf barat apabila ditelusuri lebih jauh lagi telah berakar pada fisafat hukum alam (nature law) yang sangat berkembang pada abad pencerahan (enlightenment atau aufklarung).

Hukum kontrak pada abad sembilan belas telah banyak mendapat pengaruh ajaran dari aliran filsafat yang lebih menekankan kepada individualisme ${ }^{8}$ sebagaimana telah tercermin pula dari pemikiran politik ekonomi klasik Adam Smith dan utilitarianisme Jeremy Bentham. Mereka memandang bahwa tujuan utama dari legislasi dan pemikiran sosial harus dapat menciptakan the greatest happiness for the greatest number. ${ }^{9}$ Mereka telah menjadikan kebebasan berkontrak sebagai paradigma baru dalam hukum kontrak.

Paradigma kebebasan berkontrak ini sangat berpengaruh dalam hal pembentukan peraturan perundang-undangan pada saat itu. Di negara Perancis diakui bahwa ketika Code Civil telah dikodifikasikan pada tahun 1804, maka alam pikiran orang-orang di negara Perancis sangat dipengaruhi oleh paham individualisme dan liberalisme. Termasuk Kitab UndangUndang Hukum Perdata Jerman (Burgerliches Gezetbuch/BGB) juga tidak dapat terlepas dari paradigma kebebasan berkontrak.

${ }^{4}$ K.W.Ryan, Introduction to Civil Law, The Law Book of Australia Brisbane, 1962, h. 39. Perhatikan pula P.S.Atiyah, The Rise and Fall of Freedom of Contract, Clarendon Press Oxford, 1988, h. 292. Lihat juga

F.H.Buckley, ed., The Fall and Rise of Freedom of Contract, Duke University Press, Durham, 1999, h. 25-26.

5 Peter Gillies, Businees Law, The Federation Press Sydney, 1993, h. 117.

6 P.S.Atiyah, An Introduction to the Law of Contract, Clarendon Press, Oxford, 1981, h. 8.

7 Arthur Taylor Von Mehren, The Civil Law System, Cases and Materials, Prentice Hall, Englewood, N.J, 1987, h. 470.

${ }^{8}$ Pada masa ini lahir model umum (general model) hukum kontrak klasik yang dibangun dari ideology individualisme dari era klasik. Hukum kontrak klasik sangat menekankan kebebasan berkontrak untuk mendukung ekonomi bebas pada abad sembilan belas. Lihat Grant Gilmore, The Death of contract, Ohio State University Press, Columbus, 1955, h. 6-8.

${ }^{9}$ George Gluck, Standard Form Contract The Contract Theory Reconsidered, International Law and Comparative Quaterly, vol. 28, January 1979, h. 72. 
Pada abad sembilan belas teori hukum klasik telah terbentuk. Dengan terbentuknya teori baru ini maka telah menimbulkan reaksi dan kritik terhadap tradisi abad pertengahan mengenai substantive justice. Reaksi para hakim dan sarjana hukum di negara Inggris dan Amerika Serikat telah menolak kepercayaan yang telah berlangsung lama dalam hal justifikasi kewajiban kontraktual yang diderivasi dari inherent justice atau fairness of an exchange. Para hakim dan sarjana hukum menyatakan bahwa sumber kewajiban kontraktual adalah bertemunya kehendak (convergence of the wills) atau konsensus para pihak yang telah membuat kontrak. ${ }^{10}$

Pada abad sembilan belas, para sarjana hukum kontrak memiliki kecenderungan untuk memperlakukan atau menempatkan pilihan individual (indvidual choice) tidak hanya sebagai elemen kontrak, tetapi seperti yang telah dinyatakan oleh ahli hukum Perancis yaitu sebagai kontrak itu sendiri. Para pihak memiliki kecenderungan untuk mengidentifikasikan pilihan tersebut dengan kebebasan, dan kebebasan menjadi tujuan tertinggi keberadaan individu.

Dengan adanya paradigma baru ini, maka moral dan hukum harus secara tegas dipisahkan. Pemisahan antara moral dan hukum ini telah memunculkan adagium summun jus summa injuria (hukum tertinggi dapat berarti ketidakadilan yang terbesar). Konsep seperti justum pretium laesio enomis (harga yang adil dapat berarti kerugian yang terbesar) atau penyalahgunaan hak tidak memiliki tempat di dalam doktrin ini. Dengan demikian maka apabila seseorang dirugikan oleh suatu perjanjian yang disebabkan karena kesalahannya sendiri, maka seseorang tersebut harus memikulnya sendiri dikarenakan seseorang tersebut telah menerima kewajiban itu secara sukarela (volenti non fit injuria).

Dengan kata lain dapat disimpulkan bahwa perjanjian tetap berlaku sebagai undangundang bagi para pihak yang membuatnya. ${ }^{11}$ Paradigma baru ini juga menyebabkan kontrak terbagi ke dalam dua aspek: Pertama, kebebasan untuk mengadakan suatu kontrak. Kedua, kontrak tersebut harus diperlakukan secara sakral oleh pengadilan, dikarenakan para pihak secara bebas dan tidak ada pembatasan dalam mengadakan kontrak tersebut. Maka, kebebasan kontrak dan kesucian (sanctity) kontrak menjadi dasar dari keseluruhan hukum kontrak yang telah berkembang pada

${ }^{10}$ Morton J. Horwitz, The Historical Foundation of Modern Contract Law, Havard Law Review, vol. 87, 1974, h. 917. Kebebasan berkontrak jelas sekali berkaitan erat dengan teori kehendak (will theory) yang mengajarkan bahwa pengakuan dan pelaksanaan kontrak didasarkan pada kehendak mereka yang membuat kontrak. Lihat Hein Kozt, ed., Introduction to Comparative Law, Volume IIThe Institutional of Private Law, Clarendon Press, Oxford, 1987, h. 325-326.

11 A.S. Hartkamp, ed, Mr Asser's Handleding tot beofepening van het Netherlands Burgerlijk Rechts, Verbintenissenrecht, Deel III, Algemene Leer der Overeenkomsten, W.E.J Tjeenk Willink BV, Zwole, 1989, h. 37. 
saat itu. ${ }^{12}$ Dengan kata lain, maka orientasi para pihak adalah kesucian dan kebebasan berkontrak. ${ }^{13}$

Bersamaan dengan adanya pengembangan asas konsensual, telah dikembangkan pula asas iktikad baik (bonafides). Kontrak (konsensual) harus didasarkan pada iktikad baik. Dalam perkembangannya contractus re diperluas hingga mencakup innominati, akan tetapi hukum Romawi tetap berpegang teguh pada syarat yang menyatakan bahwa perjanjian dengan sedikit pengecualian hanya dapat terjadi apabila memenuhi bentuk yang telah ditetapkan. ${ }^{14}$

Kontrak tersebut biasanya diwujudkan dalam bentuk suatu dokumen notarial. ${ }^{15}$ Dengan demikian kontrak di sini tidak berlaku aturan umum yang menerangkan bahwa lahirnya kewajiban kontraktual berdasarkan konsensus (nodus consensus obligat). ${ }^{16}$ Selain itu hukum Romawi juga mengenal pula Pacta Nuda yang tidak memiliki hak untuk menuntut (actionable pacts). ${ }^{17}$ Contractus ex Consensu di dalam hukum Romawi semakin berkembang. Terdapat kecenderungan yang mengarah kepada perlindungan terhadap kontrak yang bersifat konsensus, Namun demikian proses ini telah terhalang oleh pengaruh formalisme hukum Jerman ${ }^{18}$

Hukum Konanik pada abad pertengahan, di bawah pengaruh teori teologis, telah menerima prinsip konsensus dan mengembangkan prinsip nudus consensus obligat, pacta nuda servanda sunt. Untuk memenuhi persyaratan esensial bagi pertumbuhan generalisasi teori kontrak modern, maka dalam teori kontrak modern terjadi perubahan numeros clausus dari kontrak dengan doktrin (nodus) consensus dengan prinsip bahwa semua transaksi (kontrak) informal adalah mengikat. Prinsip ini dengan baik menghubungkan dan menjelaskan pengaruh besar dan lahirnya maksim ex nudo pacto oritur actio. Maksim ini diformulasikan untuk melawan prinsip dalam hukum Romawi nuda factio obligationem non parit. ${ }^{19}$

Sistem Civil Law yang membebaskan dirinya dari hukum Romawi yang menekankan formalisme menerima teori kontrak yang berbasis konsensus melalui

${ }^{12}$ P.S.Atiyah, Op.,Cit, An Introduction to The Law of Contract, h. 4.

${ }^{13}$ K.M.Sharma, "From Sanctity to Fairness: An Uneasy Transition in The Law of Contract", New York Law School Journal of International Law and Comparative Law, vol. 18, 1999, h. 18.

${ }^{14}$ A.S.Hartkamp, ed., Op.,Cit, h. 32.

${ }^{15}$ Reinhard Zimmermann, Op.,Cit, The Law of Obligation, Roman Foundation of Rule Civilian Tradition, h. 547.

${ }^{16}$ A.S. Hartkamp, ed., Loc.,Cit.

${ }^{17}$ Istilah Pacta berasal dari kata Pactum. Kata factum (atau factio) adalah kata yang digunakan untuk menunjukkan semua perjanjian informal yang (secara independen) tidak memiliki hak untuk menuntut (nuda factio obligationem non parit). Lihat Reinhard Zimmermann, Op.,Cit, The Law of Obligation, Roman Foundation of Rule Civilian Tradition, h. 563.

${ }^{18}$ A.S. Hartkamp ed., Op.,Cit, h. 547.

19 Reinhard Zimmermann, Loc.,Cit, Roman-Dutch Jurisprudence and it's Contribution to European Private Law. 
maksim pacta sunt servanda. ${ }^{20}$ Prinsip ini telah diterima baik dalam sistem hukum civil law maupun common law. Prinsip ini menjelaskan bahwa private individuals memiliki kebebasan untuk menentukan isi dan akibat hukum dari suatu kontrak tanpa adanya campur tangan dan pembatasan oleh hukum. Meskipun kedua sistem hukum tersebut telah menerima asas konsensual, akan tetapi keduanya memiliki sejarah dan makna yang berbeda di dalam memahami asas konsensual itu. Dalam Civil Law, prinsip ini telah memberikan gambaran bukan hanya sebagai pernyataan politik non intervensi dari negara di dalam hubungan antara individu, tetapi juga sebagai perbuatan hukum yang berbasis kontrak melalui teori otonomi kehendak. Teori otonomi kehendak sendiri merupakan permasalahan hukum dan tidak semata-mata sebagai suatu permasalahan politik sebagaimana yang telah terjadi di dalam sistem common law melalui kebebasan berkontrak.

Doktrin teori otonomi kehendak tersebut menjelaskan bahwa sumber kewajiban hukum mensyaratkan adanya suatu perbuatan hukum dan di dalam kontrak telah ditemukan melalui adanya kehendak individu untuk mengadakan suatu transaksi melalui pernyataan kehendaknya. Dalam sistem civil law, persetujuan kehendak (consensus ad idem) dan manifestasi (eksternal) kehendak merupakan suatu hal yang sangat esensial. ${ }^{21}$ Walaupun tidak ada satu ketentuan pun dalam Code Civil Perancis yang secara langsung mengacu prinsip konsensualisme tersebut, ${ }^{22}$ tetapi tidak ada keraguan bahwa para penyusun Civil Code Perancis tersebut dipengaruhi oleh ide konsensualisme yang didukung oleh Domat dan Pothier. ${ }^{23}$ Sehingga pada akhirnya, teori kehendak dan teori hukum klasik yang berasal dari prinsip private autonomy menjadi memiliki makna bahwa kehendak para pihak yang menentukan hubungan kontrak di antara para pihak. Prinsip yang demikian tersebut telah menimbulkan beberapa konsekuensi antara lain sebagai berikut: ${ }^{24}$ (1) hukum yang berlaku bagi mereka tersebut semata-mata berkaitan dengan maksud yang sebenarnya dari pihak yang berjanji; (2) maksud para pihak harus "bertemu" pada saat sebelum dibuatnya kontrak; (3) hakim tidak memiliki kewenangan untuk mengisi celah dalam suatu

${ }^{20}$ David E. Allen, et.al., eds., Asian Contract Law: A Survey on Current Problems, Melbourne University Press Carlton, 1969, h. 104.

${ }^{21}$ Ibid., h.105.

${ }^{22}$ G.H.L Fridman, "On The Nature of Contract", Valparaiso University Law Review, Vol. 17, 1993, h. 629630. KUHPerdata Indonesia juga mengakui adanya prinsip konsensualisme. Hal itu dapat disimpulkan dari Pasal 1320 KUHPerdata yang mengatur syarat-syarat sahnya perjanjian kontrak harus didasarkan pada kata sepakat di antara para pihak.

${ }^{23}$ Rudolf B. Schalesinger, Formation of Contract: A Study of The Common Core of Legal System, Stevens \& Sons, London, 1968, h. 244. Lihat juga Reinhard Zimmermann, Op.,Cit, Law of Obligation, Roman Foundation of Rule Civilian Tradition, h. 566-567. Lihat juga James Gordley, "Myths of French Civil Code", The American Journal of Comparative Law, Vol. 42, 1994, h. 469

${ }^{24}$ John Swan, et.al., Contract: Cases and Materials, Emont Montgomery, Canada, 1987, h. 134. 
kesepakatan dan tidak berdaya menghadapi kemungkinan hal yang tidak terduga; (4) pihak yang berjanji bebas mengungkapkan kemaunnya.

\section{Dasar Filosofis Kekuatan Mengikatnya Kontrak}

Akibat dari pengaruh kebebasan berkontrak, telah terjadi sakralisasi otonomi indvidu dalam kontrak. ${ }^{25}$ Otonomi individu dalam kontrak tersebut yang menjadi dasar kebebasan berkontrak yang pada akhirnya menjadi dasar dari perkembangan hukum kontrak. Munculnya pandangan terhadap kesucian kontrak merupakan salah satu ajaran yang telah dianut oleh teori hukum kontrak klasik sebagai reaksi langsung adanya kebebasan berkontrak. Kesucian kewajiban kontraktual pada dasarnya merupakan salah satu bentuk ekspresi dari prinsip yang telah menyatakan bahwa kontrak telah dibuat secara bebas dan sukarela, untuk itu kontrak tersebut disebut suci/sakral. Tidak terdapat keraguan bahwa kesucian/kesakralan kontrak tersebut merupakan produk kebebasan berkontrak, dengan alasan bahwa kontrak itu dibuat atas pilihan mereka sendiri dan juga merupakan kemauan mereka sendiri serta untuk penyelesaian isi kontrak tersebut juga berdasarkan kesepakatan bersama (mutual agreement). ${ }^{27}$

Ketaatan untuk menjalankan isi perjanjian yang sudah dibuat para pihak dalam hal ini berkaitan dengan asas facta sunt servanda. Awal mula asas ini dapat ditemukan pada doktrin praetor Romawi yaitu: facta conventa sevabo, yang artinya bahwa saya menghormati perjanjian. ${ }^{26}$ Ajaran tersebut juga didukung perintah suci motzeh sfassecha tismar (engkau harus menepati perkataanmu) ${ }^{27}$, dan dari ajaran hukum Romawi Kuno yaitu: Pacta Sunt Servanda. Konsep pacta sunt servanda ini pada akhirnya menjadi suatu konsep dasar dari teori hukum kontrak klasik. ${ }^{28}$ Konsep ini dapat ditemukan pada perjanjian antara Jehovah dan orangorang Israel (Yahudi), kegagalan untuk mematuhi isi perjanjian tersebut merupakan dosa dan melanggar kontrak. $^{29}$

${ }^{25}$ K.M. Sharma, "From Sanctity to Fairness: An Uneasy Transition in The Law of Contract", New York Law School Journal of International Law and Comparative Law, vol. 18, 1999. h. 96.

27 P.S. Atiyah, Op.,Cit, An Introduction to the Law of Contract, h. 12.

${ }^{26}$ Charles Tabor, "Dusting off The Code: Using History to Find Equity in Louisiana Contract Law", Lousiana Law Review, Vol. 68, 2008, h. 552.

${ }^{27}$ Number 30:2 (King James). Apabila seseorang membuat suatu sumpah mewajibkan dirinya sendiri untuk mematuhi ikrar tersebut, dia tidak boleh mengingkari kata-katanya, tetapi harus melakukan sesuatu apa yang harus ia lakukan. Lihat Matthew 5:33-37 (King James) dan James 1:19-25. Lihat K.M. Sharma, Op.,Cit, h. 97.

${ }^{28}$ Reinhard Zimmermann, Op.,Cit, Law of Obligation, Roman Foundation of Rule Civilian Tradition, h. 577.

${ }^{29}$ Ketika orang-orang Israel menyembah patung anak sapi jantan yang terbuat dari emas, mereka telah melakukan perbuatan dosa. Mereka melanggar kesepakatan suci dengan Jehovah. Lihat John Edward Murray, Murray on Contracts, The Michie Company, Charlottesvillie, 1990, h. 1. 
Asas Pacta Sunt Servanda dalam perkembangan sekarang ini telah mendapat banyak pengaruh dari hukum Kanonik (jus canonicus). Dokrin ini memiliki kaitan dengan dosa. Menurut ajaran gereja, semua janji mengikat dihadapan Tuhan tanpa memperhatikan bentuk janji itu. Pelanggaran terhadap perjanjian tidak tertulis tidak lebih berdosa daripada pelanggaran terhadap kontrak yang dibuat dengan sumpah atau secara tertulis. ${ }^{30}$ Semua janji yang dibuat dengan sumpah dan dengan tidak disumpah di mata Tuhan sama-sama memiliki kekuatan mengikat

Perkembangan lebih lanjut terhadap gagasan gereja ini, telah diberikan sarjana mazhab hukum alam yang telah membentuk pandangan Facta Sunt Servanda dewasa ini. Sarjana hukum Kanonik mengambil pandangan lebih jauh dengan mengatakan bahwa fides, sebagai dasar keadilan, semua janji harus mengingat dalam segala kondisi. Pandangan ini telah membentuk dasar teori klasik kontrak. ${ }^{31}$

Konsep modern dari kebebasan berkontrak telah menjadi dasar yang harus dipatuhi dalam hukum kontrak serta sekaligus sebagai hak otonomi para pihak untuk menentukan bargain mereka sendiri dan menuntut pemenuhan dari apa yang telah mereka sepakati.

\section{Prinsip Konsensualisme Dalam Kontrak Konstruksi}

Prinsip konsensualisme sebagaimana terdapat dalam Pasal 1320 butir 1 BW, bahwa kesepakatan di bentuk oleh dua unsur yaitu unsur penawaran dan unsur akseptasi. $^{32}$ Menurut prinsip ini, perjanjian itu telah lahir cukup dengan adanya kata sepakat. Penekanan dalam prinsip ini adalah adanya persesuaian kehendak (meeting of mind) sebagai inti dari hukum kontrak. Dasar keterikatan kontraktual berasal dari pernyataan kehendak, yang dibedakan dalam dua unsur yaitu kehendak dan pernyataan. Kehendak dan pernyataan (wils en verklaring) merupakan syarat penting dalam suatu perjanjian. ${ }^{33}$ Suatu perjanjian terbentuk karena adanya perjumpaan kehendak (consensus) dari pihak-pihak. Perjanjian pada pokoknya dapat dibuat bebas tidak terikat bentuk dan tercapai tidak secara formal tetapi cukup melalui konsensus belaka. ${ }^{34}$ Dengan demikian prinsip konsensualisme ini sangat penting dalam hukum kontrak, khususnya pada aspek pembentukan kontrak. Hal ini merupakan syarat mutlak dalam setiap kontrak dan berfungsi untuk menjamin kepastian hukum. ${ }^{35}$

\footnotetext{
${ }^{30}$ Charles Tabor, Loc., Cit.

31 Ibid., h. 554.

${ }^{32}$ Dalam Common Law System juga dijumpai hal yang sama yaitu adanya offer and acceptance. Periksa: E. Allan Fransworth, et.al., Cases and Materials on Contract, The Foundation Press, New

${ }^{33}$ Wiryono Projodikoro, Asas-Asas Hukum Perdata, Sumur, Bandung, h. 38.

${ }^{34}$ R. Feenstra en M. Ahsman, Contract, aspecten van de begrippen contract en contractsvrijheid in historisch perspectief, tweede druk, deventer, 1988, h. 40, dalam: Herlien Budiono, Asas Keseimbangan Bagi Hukum Perjanjian Indonesia, Citra Aditya Bakti, Bandung, 2006, h. 95.

${ }^{35}$ R. Subekti, Aspek-Aspek Hukum Perikatan Nasional, Alumni, Bandung, 1986, h. 5.
} York, 1995. h. 179-195. 
Dengan prinsip ini dipahami bahwa kontrak dianggap telah terjadi dan karenanya mengikat para pihak sejak tercapainya kata sepakat. Prinsip ini berlaku universal. Setiap kelompok sistem hukum menganut sistem ini, bahkan dalam perkembangannya prinsip konsensualisme memperoleh penjabaran lebih detail dalam legislasi di beberapa negara dalam berbagai model hukum tentang kontrak.

Titik tolak dari prinsip konsensualisme ini adalah berpangkal dari adanya pemikiran bahwa setiap perkataan adalah mengikat, merupakan tuntutan kesusilaan sebagaimana dikemukakan oleh Eggens, bahwa manusia diletakkan dalam martabatnya yang paling tinggi di antara semua mahkluk karena perkataannya, seperti ungkapan: "bahwa orang ditempatkan dalam martabat yang tertinggi sebagai manusia karena perkataannya dapat dipercaya, meletakkan kepercayaan pada perkataan seseorang berarti menganggap orang itu sebagai kesatria". ${ }^{36}$ Dalam Hukum Positif Indonesia, syarat kesepakatan merupakan syarat pertama yang tertuang dalam Pasal 1320 BW. Tidak ada penjelasan lebih lanjut mengenai hal-hal yang berhubungan dengan kata sepakat, kecuali tentang cacat kehendak sebagaimana di atur dari Pasal 1321 sampai dengan Pasal 1328 BW. Dari berbagai kepustakaan dapat disimpulkan bahwa kesepakatan adalah keadaan dimana pernyataan kehendak pihak yang satu "cocok" dengan pernyataan kehendak pihak lain. Cocok yang dimaksudkan adalah terdapat persesuaian, jadi bukan berarti sama. ${ }^{37}$

Dalam kontrak konstruksi, berlaku juga syarat-syarat yang diwajibkan dalam Pasal 1320 BW. Pihak pengguna jasa dan pihak penyedia jasa menyatakan kehendak untuk saling menyepakati yang tertuang dalam suatu dokumen kontrak. Kesepakatan terbentuknya kontrak karena proses tawar menawar dimana para pihak saling menyatakan kehendak. Apa yang dinyatakan oleh masing-masing pihak tersebut di dalam Hukum Perikatan lazim disebut sebagai pernyataan kehendak. Dua unsur dalam kesepakatan, yaitu penawaran dan akseptasi, adalah merupakan pernyataan kehendak. Untuk tercapai kesepakatan, dua unsur ini secara kumulatif harus selalu dipenuhi. Tidak ada kesepakatan tanpa penawaran, sebaliknya juga tidak ada kesepakatan tanpa akseptasi. Keabsahan suatu kontrak bergantung pada keabsahan kesepakatan, dan untuk menentukan apakah kesepakatan itu mengikat para pihak, harus dilakukan penilaian terhadap proses pembentukkannya. ${ }^{38}$ Begitu pula hal-hal yang menyangkut implikasi pembatalan atau pencabutan kembali baik penawaran ataupun akseptasi. Oleh karena itu, di dalam usaha untuk memahami kesepakatan, harus dilakukan

\footnotetext{
${ }^{36}$ Ibid, h. 6.

37 Y. Sogar Simamora, Prinsip Hukum Kontrak Dalam Pengadaan Barang dan Jasa Oleh Pemerintah, Disertasi, Program Pascasarjana Universitas Airlangga Surabaya, 2005, h. 172.

${ }^{38}$ I Wayan Wiryawan, Prinsip Hukum Kontrak Konstruksi Kaitannya Dengan Prinsip Tri Hita Karana di Bali, Disertasi, Program Pascasarjana Universitas Airlangga Surabaya, 2008, h. 128.
} 
dengan memahami dua unsur tersebut. Dengan adanya pemahaman dari kedua unsur itu, kesepakatan para pihak dalam kontrak konstruksi dapat tercapai baik dari pihak pengguna jasa maupun dari pihak penyedia jasa. Selanjutnya hasil kesepakatan itu akan dituangkan dalam suatu dokumen kontrak yang disebut dengan kontrak kerja konstruksi (yang disingkat dengan: kontrak konstruksi) sebagaimana di atur dalam Pasal 22 UU Jasa Konstruksi Jo Pasal 20 PP No.29/2000 dan jo pasal 50 perpres no 70 tahun 2012.

Pemahaman dua unsur kesepakatan yakni penawaran dan akseptasi. Penawaran sebagai unsur dari pernyataan kehendak yang mengandung maksud untuk membuat kontrak, seyogyanya penting untuk dipahami. Sebab, penawaran berarti suatu usulan atau ajakan untuk mengadakan perjanjian. Namun demikian, tidak setiap usulan dapat dinilai sebagai penawaran. Dalam penawaran harus diungkap secara jelas pokok yang diperjanjikan. Dalam kaitan ini lebih lengkap pernyataan Treitel mengenai penawaran: An offer is an expreesion of willingness to contract on specified terms, made with the intention that is shall become binding as soom as it is accepted by the person to whom it is addressed. ${ }^{39}$

Hal pokok dari perjanjian disebut dengan unsur essentialia. ${ }^{40}$ Misalnya dalam jual beli, penawaran yang dimaksud harus mengemukakan unsur essensial dari jual beli yaitu barang dan harga. Hal-hal yang tidak termasuk unsur pokok tidak harus dikemukakan dalam penawaran. Apa yang terkandung di dalam penawaran secara hukum mengikat, artinya bila pihak lain melakukan akseptasi maka isi penawaran itu berlaku untuk mengenai unsur pokok yang secara tegas telah dikemukakan, maupun unsur-unsur tambahan bila tentang hal ini juga dikemukakan. Apabila unsur tambahan tidak termasuk dari bagian yang disepakati maka mengenai apa yang tidak diperjanjikan ini berlaku: a) Aturan dalam Hukum Pelengkap (Aanvullend recht); b) Syarat yang biasa diperjanjikan (Bestendig gebruikelijke bedingen); c) Kebiasaan dan Kepatutan.

Di samping syarat pokok dari perjanjian, penawaran juga mengikat karena adanya niat (intention) untuk terikat. Syarat ini dalam sistem common law lazim disebut Intention To Create Legal Relation (ICRL). ${ }^{41}$ Penawaran dapat dilakukan secara tegas maupun secara diamdiam. Penawaran yang dilakukan secara tegas adalah penawaran yang di dalamnya terungkap dengan jelas maksud pihak yang menawarkan (offeror) baik secara tertulis maupun secara lisan. Sedangkan penawaran secara diamdiam adalah penawaran yang dilakukan dengan sikap tertentu. Penawaran melahirkan

\footnotetext{
${ }^{39}$ G.H. Trietel, Law of Contract, Sweet \& Maxwell, London, 1995, h. 174.

${ }^{40}$ R. Subekti, Aneka Perjanjian, Alumni, Bandung, 1985, h.2.

${ }^{41}$ Clive Turner, Australian Commercial Law, The Law Book Company, Sydney, 1995, h. 57.
} 
hak kehendak (wilsrecht), artinya pihak kepada siapa penawaran itu ditujukan (offeree) mempunyai hak untuk menerima atau menolak tawaran itu. Hak inilah yang kemudian menjadi dasar untuk mengukur kekuatan mengikat suatu penawaran. Namun demikian berlakunya hak ini bersifat terbatas, dalam arti terdapat suatu situasi dimana hak ini tidak berlaku lagi atau penawaran tidak mempunyai kekuatan mengikat disebabkan karena ditolak, lampau waktu atau karena penawaran ditarik kembali sebelum akseptasi. Perkecualian terhadap prinsip ini terjadi dalam situasi dimana penawaran dituangkan dalam suatu atau menjadi bagian dari suatu kontrak.

Akseptasi merupakan pernyataan penerimaan oleh pihak yang ditawari atas penawaran yang diajukan kepadanya. Akseptasi ini meliputi syarat dan ketentuan dalam penawaran. Akseptasi yang bersyarat tidak dapat dinilai sebagai akseptasi, melainkan penawaran balik (counter offer). Misalnya dalam suatu proses negosiasi, sering terjadi penawaran balik karena penerimaan tidak cocok dengan penawarannya. Apabila terjadi penawaran balik maka penawaran kehilangan kekuatannya disebabkan adanya penolakan. Menjadi pertanyaan dalam penawaran balik ini adalah, siapa yang kemudian menjadi pihak pemberi penawaran? Dalam kaitan ini yang menjadi pemberi penawaran adalah pihak yang melakukan penawaran balik (counter offer) itu. ${ }^{42}$

Terjadinya akseptasi menandai terjadinya kesepakatan. Oleh sebab itu penentuan waktu terjadinya akseptasi sangat penting. Hak dan kewajiban para pihak efektif berlaku setelah kesepakatan terbentuk. Para pihak tidak dapat menuntut sama terhadap orang lain sebelum mereka mencapai kesepakatan. Dengan demikian para pihak hanya saling terikat pada kewajiban kontraktualnya manakala mereka telah mencapai kesepakatan. Dalam kaitan dengan ini maka isu mengenai waktu terjadinya akseptasi merupakan isu penting untuk dijawab.

Perkembangan dalam bidang teknologi dan dunia usaha atau bisnis merupakan suatu perpaduan yang bergerak demikian cepat, sehingga membawa implikasi pada aspek kontrak dalam segala sisinya, termasuk pada aspek pembentukannya. Jenis-jenis transaksi bisnis baru bermunculan dengan coraknya masing-masing yang sering mengandung perbedaan karakter baik pada aspek hukum maupun pada aspek ekonominya. Perbedaan cara dan media dalam proses pembentukan ini membawa implikasi yang berbeda pula dalam menentukan kapan saat terjadinya kesepakatan pada para pihak. Kontrak konvensional yang dibentuk baik dengan cara lisan atau tertulis akan berbeda dengan kontrak yang akan dibentuk secara elektronik. Akibatnya, teori tentang terjadinya akseptasi pada kontrak konvensional ini tidak sepenuhnya dapat diterapkan pada kontrak yang dilakukan secara elektronik.

\footnotetext{
${ }^{42}$ Roger Halson terkait dengan kasus Hyde v. Wrench, Dalam: Y. Sogar Simamora, Op., Cit, h.
} 179. 
Prinsip dasar dalam menentukan waktu akseptasi adalah bahwa setiap pernyataan itu mengikat. Dalam perspektif ini maka momen ketika akseptasi itu dinyatakan, dianggap sebagai momen saat terjadinya akseptasi. Sikap diam tidak dianggap sebagai akseptasi melainkan harus tegas dinyatakan. Inilah yang kemudian menjadi dasar lahirnya teori pernyataan (Uitingstheorie). ${ }^{43}$ Dalam kaitannya dengan kontrak yang dilakukan dengan lisan atau melalui telepon, maka saat terjadinya akseptasi adalah saat ketika akseptasi itu diucapkan (dinyatakan). Dengan demikian sejak saat itulah di antara para pihak terikat secara hukum (legally binding). Menjadi permasalahan apabila proses pembentukkan itu dilakukan dengan sarana komunikasi lain, misalnya surat, telegram, fax, atau e-mail. Dalam media-media ini terdapat perbedaan waktu antara saat akseptasi dinyatakan dengan saat akseptasi itu diterima oleh pihak lawan. Berikut dipaparkan salah satu dari media yang dimaksud, yakni: media surat.

Dalam terjadinya akseptasi yang dilakukan dengan media surat, terdapat beberapa teori, misalnya teori mengetahui (Vernemingstheorie), teori pengiriman (Verzendingtheorie) dan teori penerimaan (Ontvangsttheorie) serta teori Pitlo. ${ }^{44}$ Munculnya teori-teori tersebut pada dasarnya bertitik tolak dan merupakan pengembangan teori pernyataan. Kritik yang ditujukan kepada teori pernyataan adalah pemikiran bahwa apa yang dinyatakan seseorang tidak bermakna jika tidak dikirimkan. Inilah yang menjadi landasan lahirnya teori pengiriman. Kemudian teori pengiriman memunculkan kritik bahwa surat pernyataan yang dikirimkan itu juga tidak pasti akan diterima oleh pihak lawan. Selama akseptasi belum diterima maka kesepakatan harus dianggap belum tercapai. Oleh sebab itu lebih tepat jika waktu terjadinya akseptasi adalah ketika akseptasi itu diterima. Pendirian ini kemudian menjadi dasar dalam membangun teori penerimaan. Kritik terhadap teori ini bahwa sekalipun surat pernyataan akseptasi itu diterima, belum tentu dibaca dan karenanya tidak diketahui oleh pihak lawan. Teori mengetahui kemudian lahir atas pemikiran tersebut. Sedangkan teori terakhir, yaitu teori Pitlo, didasarkan pada pertimbangan bahwa orang yang mengirimkan jawaban (akseptasi) secara patut dapat mempersangkakan bahwa pihak lawan telah mengetahui jawaban itu. Dengan demikian, teori Pitlo pada prinsipnya sama dengan teori mengetahui. Bedanya, dalam teori mengetahui, unsur mengetahui bersifat riil, sedangkan dalam teori Pitlo, unsur

${ }^{43}$ J. Satrio, Hukum Perikatan-Perikatan Yang Lahir Dari Perjanjian (Buku I), Citra Aditya Bakti, Bandung, 2001, h. 257-258.

${ }^{44}$ R. Setiawan, Pokok-Pokok Hukum Perikatan, Bina Cipta, Bandung, 1987, h. 57-59. 
mengetahui dipersangkakan. Hoge Raad dalam putusan HR 21 Desember 1933, NJ 1934, 368 dalam perkara Bosch v Van Maren, dalam kaitan ini ternyata memilih Teori Penerimaan sebagaimana dikemukakan oleh Niuwenhuis bahwa "tidak cukup bukti pada para pihak terdapat kehendak yang sesuai (cocok) untuk saling mengikatkan diri dan juga tidak cukup bila mereka menyatakan kehendak itu secara lisan atau tulisan, melainkan perlu (nodig) bahwa pernyataan kehendak itu mencapai pihak lain". 45

Media akseptasi melalui surat ini penting untuk dikaji, karena terkait dengan pengadaan lelang (tender). Lelang (tender) pada dasarnya merupakan kompetisi di antara para calon penyedian barang/jasa. Bagi pengguna jasa, lelang (tender) dimaksudkan untuk mendapatkan penawaran yang terbaik dari semua penawaran yang diajukan oleh peserta lelang. Dalam kaitan dengan syarat akseptasi dalam pembentukkan kata sepakat, maka akseptasi datang dari pihak pemerintah dan bukan dari penyedia barang/jasa. Untuk mengetahui waktu terjadinya akseptasi perlu pemahamana proses lelang (tender).

Proses pelaksanaan lelang dilakukan sesuai dengan tata cara yang telah ditentukan dalam dokumen pengadaan. Dokumen ini telah menentukan tata cara dan syarat-syarat lelang baik dalam tahap pengumuman, penyampaian penawaran dan evaluasi serta penetapan pemenang.

Proses menuju terciptanya akseptasi dalam lelang didahului dengan proses pembukaan dan evaluasi terhadap semua penawaran yang diajukan. Tahap evaluasi merupakan tahap akhir dari keseluruhan proses lelang sebelum akhirnya ditetapkan pemenang lelang oleh pengguna barang/jasa. Dalam pengadaan barang/jasa pemborongan, kriteria utama dalam menentukan pemenang lelang adalah harga terendah dan responsif. Maksudnya adalah sesuai dengan syaratsyarat esensial yang terdapat dalam dokumen pengadaan termasuk spesifikasinya. Dengan demikian walaupun harga suatu penawaran dari sisi harganya paling rendah, tidak selalu harus ditetapkan sebagai pemenang. Dalam kaitan dengan penentuan saat terjadinya akseptasi dalam lelang (tender), maka akseptasi itu terjadi pada saat diterbitkannya surat penetapan pemenang lelang dari pejabat yang berwenang. Sejak saat itulah penawaran yang diajukan oleh peserta lelang harus dianggap telah diakseptasi karena penawaran tersebut berdasarkan evaluasi yang merupakan penawaran yang terbaik dan menguntungkan pemerintah. Hal ini merupakan konsekuensi hukum dari metode pemilihan penyedia barang/jasa melalui lelang, yaitu mendapatkan penawaran yang

\footnotetext{
45 JH. Niuwenhuis, Pokok-Pokok Hukum Perikatan, terjemahan D.Saragih, Surabaya, 1985, h.
} 182. 
terbaik, sehingga jika dari hasil evaluasi telah ditentukan, sejak saat itulah akseptasi dianggap telah diberikan. Syarat kesepakatan dalam pembentukkan kontrak konstruksi dengan demikian telah terpenuhi sejak ditetapkannya pemenang lelang.

Sejalan dengan proses menuju terciptanya akseptasi dalam lelang, hal tersebut menunjukkan adanya langkah maju yang bisa mengurangi tingkat kebocoran pada proyekproyek pengadaan barang/jasa. Pada dasarnya pengadaan barang/jasa dapat dikelompokan menjadi: 1) Pengadaan jasa konsultansi; b) Pengadaan Jasa Pemborongan; c) Pengadaan Jasa lainnya.

Jasa konsultasi adalah layanan jasa keahlian profesional dalam berbagai bidang untuk mencapai sasaran tertentu yang keluarannya berbentuk piranti lunak yang disusun secara sistematis berdasarkan kerangka acuan kerja yang ditetapkan oleh Pejabat Pembuat Komitmen (disingkat PPK). Ruang lingkup jasa konsultasi konstruksi meliputi jasa perencanaan atau pengawasan konstruksi yang meliputi pekerjaan arsitektur, sipil, mekanikal, dan tata lingkungan yang hasil pekerjaannya dapat berupa bangunan atau bentuk fisik lain. Sedangkan jasa konsultasi non-konstruksi merupakan semua layanan jasa keahlian yang tidak termasuk dalam kategori jasa perencanaan atau pengawasan konstruksi.

Jasa perencanaan konstruksi, ruang lingkup kegiatannya antara lain terdiri atas: 1) Kegiatan pada tahap persiapan yang meliputi mengumpulkan data dan informasi lapangan, membuat penafsiran secara garis besar terhadap arahan penugasan, melakukan konsultasi dengan pemerintah daerah setempat mengenai segala sesuati yang berhubungan dengan rencana pembangunan dan ijin; 2) Menyusun pra rancangan yang meliputi rancangan tapak, perkiraan biaya, mengurus untuk mendapatkan ijin prinsip atau advise planning dari pemerintah daerah setempat; 3) Menyusun pengembangan rancangan pelaksanaan yang meliputi pembuatan rancangan arsitektur, membuat rancangan struktur dan kegunaan serta analisis perhitungan; 4) Menyusun rancangan detail yang meliputi pembuatan gambar-gambar detail, Rencana Kerja dan Syarat-syarat (RKS), rincian volume pekerjaan, Rencana Anggara Biaya (RAB) dan menyusun dokumen perencanaan; 5) Mempersiapkan pelelangan yang meliputi penyusunan dokumen lelang, membantu panitia lelang dalam menyusun program lelang;

Sedangkan pada jasa pengawasan konstruksi, ruang lingkup kegiatannya antara lain terdiri atas: 1) Memeriksa dan mempelajari dokumen kontrak yang akan dijadikan dasar dalam tugas pengawasan; 2) Mengawasi pelaksanaan pemakaian material, peralatan, serta metode pelaksanaan, mengawasi ketepatan waktu dan pembiayaan konstruksi; 3) Mengawasi pelaksanaan konstruksi dari aspek kualitas, kuantitas, dan laju pencapaian volume pekerjaan; 4) Menginventarisasi perubahan dan penyesuaia 
yang dilakukan di lapangan berkait dengan permasalahan yang timbul; 5) Menyusun berita acara persetujuan kemajuan pekerjaan.

Selanjutnyua, Jasa pemborongan merupakan layanan pekerjaan pelaksanaan konstruksi atau wujud fisik lainnya yang perencanaan teknis dan spesifikasinya ditetapkan oleh PPK dan proses serta pelaksanaannnya diawasi oleh PPK. Terakhir, jasa lainnya adalah segala pekerjaan dan atau penyediaan jasa selain jasa konsultasi, jasa pemborongan, dan pemasokan barang. Jasa lainnya meliputi antara lain: Jasa boga/katering, jasa perawatan komputer dan layanan, jasa percetakan dan penjilidan, jasa ekspor-impor, jasa periklanan, jasa penjahitan/konveksi, jasa pemeliharaan/perbaikan alat/peralatan kantor, jasa asuransi, jasa penyewaan alat konstruksi dan lainnya. Dari uraian tersebut diatas, dimana akseptasi dalam pemilihan penyedia barang/ jasa dalam kaitannya dengan kontrak konstruksi, adalah dimaksudkan untuk mendapatkan penawaran yang terbaik dari semua penawaran yang diajukan oleh peserta.

\section{Itikad Baik Dalam Pembentukan Kontrak dan Negosiasi}

Dalam studi hukum kontrak modern, prinsip itikad baik (good faith) merupakan salah satu isu yang selalu mendapatkan perhatian istimewa khususnya dalam studi perbandingan hukum. ${ }^{46}$ Dikotomi civil law dan common law, di antaranya terletak pada penerapan prinsip ini dalam proses kontrak. ${ }^{47}$ Sebagai suatu kewajiban hukum, prinsip yang berakar dari Hukum Romawi ini berkembang kira-kira sejak tahun 1870an pada masa kelahiran ajaran legal positivism dan the laissez-faire theory yang menjadi basis dari teori hukum kontrak klasik. Sekalipun terdapat perbedaan penekanan pada daya kerjanya, prinsip ini dapat dikatakan telah diterima secara universal sebagai prinsip umum dalam hukum kontrak sebagaimana nampak dari substansi konvensi CISG dan model hukum PICC dan PECL.

Pada mulanya dipahami bahwa kewajiban itikad baik atau bonafides berlaku pada saat para pihak melaksanakan kontrak. Tetapi dalam perkembangannnya daya kerja prinsip ini diletakkan tidak saja pada tahap pelaksanaan namun juga pada tahap pra kontrak, yakni ketika para pihak melakukan perundingan untuk mencapai kesepakatan. Titik tolaknya adalah tahun 1861 yakni ketika Rudolf von Jhering

46 Studi perbandingan itu misalnya seperti yang tertuang dalam, Sjef van Erp, "The Precontractual Stage", dalam "Materials European Contract Law", J.M. van Dunne, ed., 2003/2004, h. 9596.

47 Prinsip itikad baik ini juga dikenal dan diterapkan dalam system common law namun penekanannya hanya pada aspek pelaksanaan (contractual performance). Lihat misalnya, Allan E. Farnsworth, h. 278-279, Woo Pei Yee, "Protecting Parties Reasonable Expectations: A General Principle of Good Faith", Oxford University Commonwealth Law Journal, Vol. 1 No. 2, Winter 2001, h. 211-213. P.S. Atiyah, "The Binding Nature of Contractual Obligations", dalam Contract Law Today (Anglo-French Comparison), Donald Harris, ed., Clarendon Press, Oxford, 1989, h. 26-27. 
mengintrodusir konsep culpa in contrabendo, tanggung gugat yang lahir karena kesalahan yang dilakukan dalam negosiasi.

Tanggung gugat tidak saja lahir karena tidak dilaksanakannya kewajiban kontraktual, Tetapi juga apabila salah satu pihak melalaikan kewajiban hukum dalam tahap perundingan yakni kewajiban beritikad baik. ${ }^{48}$ Pandangan yang demikian semakin meluas terutama ketika negaranegara memandang perlu untuk meningkatkan kerja sama ekonomi dan perdagangan yang pada akhirnya memunculkan isu harmonisasi hukum dalam sector hukum privat, khususnya kontrak dagang internasional, meluas di era $1980 .{ }^{49}$ Dan semakin menguat pada 1990-an. ${ }^{50}$

Sekalipun prinsip itikad baik telah diterima secara luas sebagai salah satu bentuk kewajiban hukum bagi para pihakl dalam setiap tahapan dari kontrak, tetapi tidak banyak yang memberikan batasan tentang makna prinsip ini. Dalam BW pun tidak dijumpai batasan itikad baik. Begitu juga PICC dan PECL, sekalipun mengatur tentang kewajiban beritikad baik, kedua model hukum ini tidak memberikan batasan itikad baik. Sebaliknya, UCC Amerika Serikat justru memberikan definisi, sekali pun secara umum sebagaimana nampak dari Section 2-103 yang secara khusus diperuntukkan bagi pedagang yang merumuskan "Good Faith' means honesty in fact and the observance of reasonable commercial standards of fair dealing in the trade." Dengan demikian dalam UCC itikad baik disamping dimaknai sebagai perilaku jujur juga dikaitkan dengan fair dealing. Akal sehat maka billijkheid berkaitan dengan perasaan yakni mengenai apa yang dapat dirasakan sebagai sopan, patut dan adil. Dengan demikian itikad baik meliputi semua yang dapat ditangkap baik dengan intelek maupun dengan perasaan. Dalam usaha untuk mengetahui ada tidaknya itikad baik dalam suatu hubungan kontraktual, terdapat dua jenis pengujian, yaituu pengujian obyektif (objective test) dan pengujian subjektif (subjective test). Jenis yang pertama berkaitan dengan kepatutan, dalam arti salah satu pihak tidak dapat membela diri dengan mengatakan bahwa ia telah bertindak jujur manakala ternyata ia tidak bertindak secara patut. Sedangkan dalam pengertian kedua, subjective test, kewajiban itikad baik dikaitkan dengan keadaan karena ketidaktahuan (lack of notice), misalnya dalam perolehan hak milik atas benda bergerak yang diserahkan oleh orang yang tidak

48 Penerapan ajaran culpa in contrabendo di Jerman ternyata lebih luas, dalam arti juga membebankan kewajiban untuk berhati-hati (duty of care) terhadap pihak ketiga ketika negosiasi berlangsung. Ini misalnya dalam kasus yang disebut salad-leaf case, dalam mana seorang anak yang mengikuti ibunya berbelanja di suatu super market terpeleset dan jatuh karena menginjak daun salad. Mahkamah Agung Jerman memutuskan sekalipun sang anak tidak terlibat dalam tahap pra-kontraktual, super market dinyatakan bersalah karena melanggar kewajiban berhati-hati (duty of care).

49 Artikel 7 CISG (1980) yang mewajibkan penafsiran terhadap konvensi ini juga dilakukan dengan memperhatikan kewajiban beritikad baik.

50 Era ini ditandai dengan kelahiran PICC, dan di tahun 2002 menyusul PECL yang telah tersusun lengkap berikut revisinya. 
berhak. Pengertian bonafides yang kemudian diterjemahkan menjadi itikad baik itu masuk dalam jenis yang pertama. ${ }^{51}$ Dalam system common law maknanya sama dengan konsep reasonableness and equity. Equity, yang didalam strukturnya terkandung prinsip itikad baik, adalah " $a$ body of rules evolved to mitigate the severity of the rules of the common law".

Memahami makna itikad baik bukanlah hal yang mudah sebab pengertian itikad baik dengan kewajaran atau kepatutan (redelijkheid atau reasonableness) sering tumpang tindih. Seperti nampak dalam batasan itikad baik oleh HR di atas, dalam itikad baik terkandung kepatutan. Sebaliknya, didalam pengertian kepatutan (reasonableness) terkandung juga kewajiban beritikad baik. Tentang hal ini dapat dilihat rumusan kepatutan (reasonableness) dalam Artikel 1.302 PECL yang menentukan sebagai berikut:

Under these principles reasonableness is to be judge by what persons acting in good faith and in the same situation as the parties would consider to be reasonable. In particular, in assessing what is reasonable the nature and purpose of the contract, the circumstances of the case, and the usages and practices of the trades or professions involved should be taken into account.

Itikad baik dan kepatutan dengan demikian memang dipahami sebagai prinsip yang saling melengkapi (complementary). Di dalam itikad baik terkandung kewajiban untuk berlaku secara patut, demikian juga dalam kepatutan terkandung kewajiban untuk beritikad baik. Dalam kaitan dengan penerapan kewajiban itikad baik pada tahap negosiasi, menarik untuk disimak putusan HR tanggal 18 Juni 1982, NJ 1983 dalam perkara antara Plas v Valburg. Dalam kasus ini suatu perusahaan konstuksi mengikuti tender untuk pembangunan kolam renang milik pemerintah kota Valburg. Penawaran perusahaan tersebut adalah yang terbaik baik dari sisi perencanaan maupun pembiayaan namun keputusan penetapan pemenang lelang harus terlebih dahulu memperoleh persetujuan dewan kota. Ternyata satu anggota dewan mengambil inisiatif untuk menyelenggarakan tender alternatif yang kemudian memenangkan

${ }^{51}$ Mengenai pengertian itikad baik yang kedua, hanya dapat diterapkan karena ketidaktahuan pembeli bahwa penjual bukan orang yang berhak, yang dalam perspektif Indonesia dapat saja terjadi karena ketentuan yang diatur dalam pasal 1977 ayat (1) BW. Dengan demikian tidak termasuk perolehan hak karena pemberian atau hibah (schenking). Inilah yang oleh Scholten disebut sebagai rechtsverfijning. Perlindungan atas dasar prinsip itikad baik karenanya hanya dapat diberikan pada pembeli benda bergerak (tidak terdaftar). Sementara mengenai jual beli hak atas tanah, prinsip tersebut tidak dapat diterapkan karena bagi pembeli terletak kewajiban untuk meneliti obyek dan status penjual sebelum pembelian dilakukan. Kewajiban pembeli ini juga merupakan kewajiban yang didasarkan pada prinsip itikad baik; pelanggaran terhadap kewajiban ini menyebabkan ia (pembeli) tidak akan dikualifikasikan sebagai pembeli yang beritikad baik dan karenanya tidak dilindungi. Putusan Mahkamah Agung RI No. 1816 K/Pdt./1989, tanggal 22 Oktober 1992 dalam perkara antara lucky iwanto v. A. Tohir bin Rahman, dkk. Dan Pemerintah Republik Indonesia. 
perusahaan lain yang mengajukan penawaran dengan harga yang lebih rendah. Akhirnya dewan kota menyetujui proposal yang diajukan perusahaan tersebut dan usulan Plas dikesampingkan. Atas gugatan ganti rugi yang diajukan oleh Plas, yang pada akhirnya menjadikan putusan dalam perkara ini sebagai landmark decision.

Dalam tahapan negosiasi yang terakhir, terdapat situasi di mana para pihak telah mencapai kesepakatan yang kemudian dituangkan dalam kontrak, pengadilan akan menerapkan perlindungan atas dasar prinsip itikad baik. Pada tahap ini sebenarnya bukan lagi tahap negosiasi melainkan telah masuk pada tahap penutupan kontrak. Sedangkan pada tahap kedua, perlindungan bagi pihak yang dirugikan karena dihentikannya negosiasi, instrument perlindungan hukumn yang digunakan adalah perbuatan melanggar hukum; pihak yang dirugikan dapat mengajukan gugatan perbuatan melawan hukum (onrechtmatige daad) jika timbul kerugian baik yang menyangkut kepentingan pribadi maupun kepentingan masyarakat luas, seperti dikatakan oleh Van Dunne berikut ini:Terkait dengan upaya hukum bagi pihak yang dirugikan karena diputuskannya negosiasi seperti yang dikemukakan Van Dunne di atas, menjadi lebih terang lagi khususnya menyangkut petitum yang dapat diajukan oleh penggugat dari pernyataan oleh Hartkamp berikut ini:

The Supreme Court has decided that parties when negotiating a contract, must act according to criteria of reasonableness and equity, which impose on each of them the duty to take into account the other reasonable interest. According to recent decisions, this general duty may imply that a party lacks the freedom to break off negotiations. or when negotiations have been broken off, he is under an obligation to pay damages. These damages may even amount to the expectation loss, including the loss of profits, which the plaintiff would have made from the envisaged contract had it been concluded.

Dalam kaitan dengan pengaturan tanggung gugat tersebut, PICC telah lebih awal menerapkannya dibanding PECL sekalipun judul yang digunakan berbeda. Artikel 2.15 PICC, dengan judul Negotiations In Bad Faith, mengatur sebagai berikut;

1) A party is free to negotiate and is not liable for failure to reach an agreement; (2) However, a party who negotiates or break off negotiations in bad faith is liable for loses caused to the other party; (3) It is bad faith, in particular, for party to enter into or continue negotiations when intending not to reach an agreement with the other party.

Baik dari rumusan PICC maupun PECL nampak bahwa para pihak mempunyai kebebasan dalam melakukan negosiasi. Aturan umum yang berlaku adalah para pihak tidak bertanggung gugat dalam terjadi kegagalan dalam pembentukan kontrak. Tanggung gugat atas kerugian yang diderita pihak lain lahir karena dua factor penyebab, yaitu: pertama, jika negosiasi itu dilakukan dengan melanggar itikad baik, dan kedua, jika salah satu pihak melakukan penghentian negosiasi dengan melanggar prinsip itikad baik. Basis tanggung gugat baik untuk jenis yang pertama maupun yang 
kedua adalah perbuatan melanggar hukum. Dalam bagian penjelasan PECL disebutkan, jenis kerugian yang dapat dituntut adalah penggantian atas biaya-biaya yang telah dikeluarkan (expenses) termasuk hak menuntut kompensasi atas hilangnya kesempatan (lost opportunity) untuk membuat kontrak lain dengan pihak ketiga (negative interest). ${ }^{52}$

\section{Pelaksanaan Kewajiban Kontraktual dalam Fase Pelaksanaan Kontrak Konstruksi}

Dalam pandangan Hukum Perikatan, yang dimaksud dengan pembayaran adalah pelaksanaan kewajiban kontraktual. Kewajiban kontraktual yang dimaksud disini adalah memahami pembayaran dalam arti yang luas yaitu mengarah kepada pemenuhan prestasi dalam suatu perjanjian. Mengutip bunyi Pasal 1382 BW yang menerangkan:

Tiap-tiap perikatan dapat dipenuhi oleh siapa saja yang berkepentingan, sepertinya seorang yang turut berutang atau seseorang penanggung utang. Suatu perikatan bahkan dapat dipenuhi juga oleh seorang pihak ketiga, yang tidak mempunyai kepentingan, asal saja orang pihak ketiga itu bertindak atas nama dan untuk melunasi utangnya si berutang, atau jika ia bertindak atas namanya sendiri, asal ia tidak menggantikan hakhak si berpiutang.

Dari bunyi pasal tersebut diatas, maka yang dimaksud dengan pembayaran oleh

Hukum Perikatan bukanlah sebagaimana yang telah ditafsirkan dalam bahasa seharihari, yakni pembayaran tidak hanya dalam bentuk penyerahan sejumlah uang, akan tetapi juga turut serta pada pelaksanaan prestasi lainnya yang telah disesuaikan dengan bentuk dari perjanjian yang telah disepakati. Misalnya di dalam perjanjian kredit, yang dimaksud pembayaran dapat diartikan sebagai bentuk penyerahan uang kepada pihak kreditur sebagai bentuk pengembalian ataupun pelunasan uang pinjaman. Sedangkan perjanjian jual beli berbeda, perbedaannya terlihat pada pembayaran harga barang yang juga diikuti oleh penyerahan obyek jual beli dari penjual kepada pembeli yang dapat didefinisikan bahwa perjanjian jual beli antara pihak penjual dan pembeli telah berakhir. Dengan berakhirnya perjanjian jual beli ini maka berakhir juga kewajiban dari pihak ketiga yang bertindak sebagai penanggung, penanggung disini baru akan berakhir manakala si penanggung tersebut telah menyelesaikan kewajibannnya sesuai dengan ketentuan kontrak pertanggungan yang telah disepakati. Dengan terjadinya pembayaran, maka terlaksanalah perjanjian kedua belah pihak. ${ }^{55}$ Pada dasarnya beban pelaksanaan kewajiban atas suatu kontrak terletak pada debitur, sedangkan pelaksanaan kewajiban oleh pihak ketiga sebagaimana disebutkan dalam Pasal 1382

${ }^{52}$ Bagian penjelasan (Comment) Artikel 2.301 PECL dan Artikel 2.15 PICC. Negative interest atau biasa juga disebut negative contract interest, lazimnya dihadapkan dengan positive interest atau positive contract interest, yang pertama adalah kerugian (losses) sedangkan yang kedua adalah kehilangan keuntungan (lost profits). 
BW adalah pengecualian terhadap prinsip pembayaran di dalam perikatan. Kaitannya dengan kontrak konstruksi, kewajiban pihak pertama selaku pengguna barang/jasa adalah membayar harga yang telah disepakati dalam kontrak, sedangkan pihak kedua selaku penyedia barang / jasa dalam bidang konstruksi memiliki kewajiban kontraktual dalam hal pemenuhan berbagai macam prestasi yang terkandung di dalam kontrak.

\section{Prinsip Privity of Contract Dalam Pelaksanaan Kontrak Konstruksi}

Prinsip Privity of Contract sebagaimana terkandung di dalam Pasal 1340 BW membawa akibat bahwa subkontraktor tidak dapat secara langsung menuntut kepada pengguna barang/ jasa sekalipun terjadinya subkontrak itu didasarkan pada persetujuan pengguna barang/jasa demikian juga sebaliknya. ${ }^{53}$

Prinsip dasar dalam memberikan persetujuan subkontrak adalah subkontrak tersebut diperbolehkan apabila prestasi dari subkontrak tersebut tergolong prestasi perikatan yang dapat diganti. Disini memiliki tujuan yang jelas yaitu untuk mencegah agar prestasi dari pihak yang menerima subkontrak tidak lebih rendah dari prestasi yang telah ditentukan dalam kontrak pokoknya sehingga disini tidak menimbulkan kerugian bagi negara.

Dalam dokumen kontrak terdapat kelaziman pengaturan mengenai klausula subkontrak. Klausula subkontrak ini pada intinya mengatur dalam hal penyedia barang/jasa akan melakukan subkontrak maka penyedia barang/jasa memiliki kewajiban untuk meminta persetujuan dari pengguna barang/jasa. Hal ini juga diatur oleh Directive Uni Eropa dalam pasal 37 yang menjelaskan subcontracting sebagai berikut:

in the contract document, the contracting entity may ask, or may be required by a member State to ask the tendered to indicate in his tender any share of the contract be intends to subcontract to third parties and any proposed subcontractors. This indication shall be without prejudice to the question of principal economic operator's liability

\section{Prinsip Confidentially Dalam Pelaksanaan Kontrak Konstruksi}

Dalam perspektif Hukum Kontrak klausula confidentiality merupakan jenis prestasi untuk tidak berbuat sesuatu. ${ }^{54}$ Hakikat dari klausula confidentiality adalah larangan untuk berbuat sesuatu. Apabila klausula ini dilanggar maka akan menimbulkan tanggung gugat.

BW Indonesia tidak menjelaskan mengenai apa yang dimaksud dengan confidential, penjelasan mengenai confidential dapat ditemukan dalam PICC yaitu dalam pasal 2.16 PICC dengan judul Duty of Confidentiality yang menjelaskan sebagai berikut:

\footnotetext{
${ }^{53}$ Mariam Darus Badrulzaman, Kompilasi Hukum Perikatan, Citra Aditya Bakti, Bandung, 2001, h. 116 .

${ }^{54}$ Ibid., h. 262.
} 
where information is given as confidential by one party in the course of negotiations, the other party is under a duty not to disclose that information or to use it improperly for its own purposes, whether or not a contract is subsequently concluded. Where appropriate, the remedy for breach of that duty may include compensation based on the benefit received by the other party.

Berdasarkan penjelasan tersebut, dapat terlihat bahwa confidentiality berlaku di dalam tahap negosiasi. Informasi yang telah diberikan oleh salah satu pihak sebagai sebuah rahasia dalam tahap negosiasi menimbulkan kewajiban bagi pihak lain untuk menjaganya. Prinsip dasarnya adalah tidak ada kewajiban umum untuk menyimpan setiap informasi yang terungkap dalam suatu negosiasi sebagai suatu rahasia. ${ }^{55}$ Prinsip Confidentiality pada dasarnya untuk melindungi kepentingan penyedia barang/jasa. Dalam kaitannya dengan kontrak pengadaan dalam hal ini adalah kontrak konstruksi maka kewajiban untuk menjaga kerahasiaan terletak pada pejabat yang berwenang (contracting authority).

\section{KESIMPULAN}

Agar terciptanya penyelenggaraan jasa konstruksi yang memenuhi asas kejujuran dan keadilan, manfaat, keserasian, keseimbangan, kemandirian, keterbukaan, kemitraan dan keselamatan demi kepentingan masyarakat, bangsa dan negara (Pasal 2 Undang-Undang Nomor 18 Tahun 1999 Tentang Jasa Konstruksi). Maka baik pengguna jasa maupun penyedia jasa harus memahami beberapa hal yang mendasar yaitu: a) Landasan Filosofis Hubungan Kontraktual Antara Pemberi Jasa Konstruksi dengan Penyedia Jasa Konstruksi dan Pengawas Jasa Konstruksi; a) Prinsip dan Norma Hukum Fase Pembentukan Kontrak Konstruksi; c) Prinsip dan Norma Hukum Fase Pelaksanaan Kontrak Konstruksi.

\section{DAFTAR BACAAN}

\section{Buku}

Allen, David E. et.al., eds., Asian Contract Law: A Survey on Current Problems, Melbourne University Press Carlton, 1969.

Badrulzaman, Mariam Darus, Kompilasi Hukum Perikatan, Citra Aditya Bakti, Bandung, 2001.

Buckley, F.H., ed., The Fall and Rise of Freedom of Contract, Duke University Press, Durham, 1999.

Budiono, Herlien., Asas Keseimbangan Bagi Hukum Perjanjian Indonesia, Citra Aditya Bakti, Bandung, 2006.

${ }^{55}$ Dalam bagian penjelasan (comment) Artikel 2.16 PICC. 
Dunne, Jan M. van, Precontractual Liability, Report to the XXXth Congress International Academy of Comparative Law, Montreal Canada, 18 - 24 August 1990, E.H. Hondius, ed., Kluwer, Devender,

Emmett, Arthur R, "Roman Traces in Australian Law", Australian Bar Review, Vol. 20, 2001.

Erp, Sjef van, "The Pre-contractual Stage", dalam "Materials European Contract Law", J.M. van Dunne, ed., 2003/2004.

Fransworth, E. Allan, et.al., Cases and Materials on Contract,The Foundation Press, New York, 1995.

Feenstra, R. en M. Ahsman., Contract, aspecten van de begrippen contract en contractsvrijheid in historisch perspectief, tweede druk, deventer, 1988.

Gordley, James, "Myths of French Civil Code", The American Journal of Comparative Law, Vol. 42, 1994.

Gillies, Peter, Businees Law, The Federation Press Sydney, 1993.

Guest, A.G, ed., Chitty on Contract, Vol. I General Principles, Sweet \& Maxwell, London, 1983.

Hartkamp, A.S., ed, Mr Asser's Handleding tot beofepening van het Netherlands Burgerlijk Rechts, Verbintenissenrecht, Deel III, Algemene Leer der Overeenkomsten, W.E.J Tjeenk Willink BV, Zwole, 1989.

Kozt, Hein, ed., Introduction to Comparative Law, Volume II- The Institutional of Private Law, Clarendon Press, Oxford, 1987.

Mehren, Arthur Taylor Von, The Civil Law System, Cases and Materials, Prentice Hall, Englewood, N.J, 1987.

Murray, John Edward, Murray on Contracts, The Michie Company, Charlottesvillie, 1990.

Niuwenhuis, JH., Pokok-Pokok Hukum Perikatan, terjemahan D.Saragih, Surabaya, 1985.

Passer, Max, Romainches Privatrecht, terjemahan Rolf Dannenbring, University of South Africa, Pretoria, 1984.

Projodikoro, Wiryono., Asas-Asas Hukum Perdata, Sumur, Bandung, 1992.

Ryan, K.W., Introduction to Civil Law, The Law Book of Australia Brisbane, 1962.

Satrio, J., Hukum Perikatan-Perikatan Yang Lahir Dari Perjanjian (Buku I), Citra Aditya Bakti, Bandung, 2001.

Setiawan, R., Pokok-Pokok Hukum Perikatan, Bina Cipta, Bandung, 1987.

Simamora, Y. Sogar., Hukum Kontrak Pengadaan Barang dan Jasa Pemerintah di Indonesia, Laksbang Justitia, Surabaya, 2013.

Y. Sogar., Prinsip Hukum Kontrak Dalam Pengadaan Barang dan Jasa Oleh Pemerintah, Disertasi, Program Pascasarjana Universitas Airlangga Surabaya, 2005.

Subekti, R., Aneka Perjanjian, Alumni, Bandung, 1985.

, Aspek-Aspek Hukum Perikatan Nasional, Alumni, Bandung, 1986. 
Sharma, K.M., From Sanctity to Fairness: An Uneasy Transition in The Law of Contract, New York Law School Journal of International Law and Comparative Law, vol. 18, 1999.

Swan, John, et.al., Contract: Cases and Materials, Emont Montgomery, Canada, 1987.

Trietel, G.H., Law of Contract, Sweet \& Maxwell, London, 1995.

Turner, Clive., Australian Commercial Law, The Law Book Company, Sydney, 1995.

Thomas, J.A.C, Textbook of Roman Law, North-Holland Publishing Company, Amsterdam, 1976.

Watson, Alan, Society and Legal Change, Temple University Press, Philadelphia, 2001.

Zimmermann, Reinhard, The Law of Obligation, Roman Foundation of Rule Civilian Tradition, Juta \& Co. Ltd, Cape Town, 1992.

United Nations Convention on Contracts for the International Sale of Goods, 1980.

UNIDROIT Principles of International Commercial Contracts, Roma, 1994.

The Principles of European Contract Law, 2002.

Directives 2004/17/EC of The European Parliament and of the Council of 31 March 2004 on the Coordination of Procedures for the Award of Public Works Contracts, Public Supply Contracts and Public Service Contracts.

\section{Jurnal}

Fridman, G.H.L, "On The Nature of Contract", Valparaiso University Law Review, Vol. 17, 1993.

Gluck, George, "Standard Form Contract The Contract Theory Reconsidered", International Law and Comparative Quaterly, vol. 28, January 1979.

Horwitz, Morton J, "The Historical Foundation of Modern Contract Law", Havard Law Review, vol. 87, 1974.

Messe, Alan J., "Liberty and Antitrust in the Formative Era", Boston University Law Review, vol. 79, 1999.

Tabor, Charles, "Dusting off The Code: Using History to Find Equity in Louisiana Contract Law", Lousiana Law Review, Vol. 68, 2008.

Zimmermann, Reinhard, "Roman-Dutch Jurisprudence and it's Contribution to European Private Law", Tulane Law Review, Vol. 66, 1992. 